\begin{tabular}{|l|l|l|l|l|}
\hline ACTA CARSOLOGICA & $31 / 3$ & 8 & $139-154$ & LJUBLJANA 2002 \\
\hline
\end{tabular}

COBISS: 1.08

\title{
FROM DOLINE DISTRIBUTION TO TECTONIC MOVEMENTS EXAMPLE OF THE VELEBIT MOUNTAIN RANGE, CROATIA
}

\section{POVEZAVA MED RAZPOREDITVIJO VRTAČ IN TEKTONIKO: PRIMER GORSKE VERIGE VELEBIT NA HRVAŠKEM}

\author{
SANJA FAIVRE $^{1} \&$ PHILIPPE REIFFSTECK ${ }^{2}$
}

${ }^{1}$ Zagreb University, Geography Department, Marulićev trg 19/II, BP 595, 10000 ZAGREB, CROATIA (sfaivre@public.srce.hr).

${ }^{2}$ Laboratoire Central des Ponts et Chaussées, 58 Boulevard Lefebvre 75732 PARIS cedex 15, FRANCE, (Philippe.Reiffsteck@lcpc.fr). 
Sanja Faivre \& Philippe Reiffsteck: Povezava med razporeditvijo vrtač in tektoniko: primer gorske verige Velebit na Hrvaškem

Članek obravnava povezavo med tektonskimi silami in kraškimi površinskimi oblikami. Smer deformacij in napetosti v Velebitskem masivu smo izračunali na osnovi razporeditve vrtač z uporabo metode "center-center" (Ramsay, 1967; Fry 1979). 623 rezultatov lokalnih meritev smo vnesli v 2D model končnih elementov, ki deluje v programskem okolju Castem 2000. Ta na osnovi deformacij izračuna tektonske pogoje, ki tem deformacijam ustrazajo. Rezultati se v veliki meri ujemajo z GPS meritvami in rezultati geološkega kartiranja. Ključne besede: vrtače, tektonika, metoda končnih elementov, Velebit, Hrvaška.

\section{Abstract}

UDC: 551.44:551.24(497.5)

\section{Sanja Faivre \& Philippe Reiffsteck: From doline distribution to tectonics movements example of the} Velebit mountain range, Croatia

The influence of tectonic forces on karst relief development has been studied using dolines as geomorphological markers. The strain and stress orientations have been calculated from the doline distribution, applying the centre to centre method (Ramsay, 1967; Fry, 1979). 623 local results have been obtained which were later injected into a 2D finite element model created in Castem 2000 software. As the observed deformations are the consequence of the tectonic displacements, the numerical model tends to simulate the tectonic conditions, which are closely related to the observed deformations. The results were correlated with the GPS measurements as well as with the geological field mapping results and great coincidence was observed.

Key words: dolines, tectonics, finite element method, Velebit mountain range, Croatia. 


\section{INTRODUCTION}

The most numerous and widespread karstic form, the doline, seems to be strongly related to tectonic activity. Even if the development of dolines is primarily the consequence of the rock nature and climatic conditions, its spatial repartition is mainly determined by the geological structure. The spatial analysis of dolines allows us the determination of strain and stress orientation to which the studied area has been submitted during recent periods (Faivre \& Reiffsteck, 1999a; Faivre \& Reiffsteck, 1999b; Faivre \& Bocquet, 1999).

This analysis has been done by means of the centre to centre method (Ramsay, 1967; Fry, 1979) and the projection method (Panozzo, 1984), which were both adapted to the study of dolines. The centre to centre method permits us to define the strain ellipsoids. The method considers that the initial distance between the centres of two markers, nearest neighbours, of one population with random distribution in undeformed material, is statistically the same in any direction of measurement. But after deformation, these distances will increase following the $\lambda_{1}$ and reduce following $\lambda_{3}$ depending on the type of the finite strain ellipsoid. The major modification on this method is the fact that dolines do not have random distribution before deformation, their position being directly related to the geological structure. The 623 results (Fig. 1) obtained on the local scale were later synthesized using Panozzo's projection method, (Fig. 2), (Panozzo, 1984) which aims to analyze the two-dimensional strain presented as the preferred orientation.

The results obtained for the Velebit mountain range are in accordance with the movement of the Adriatic microplate (Anderson \& Jackson, 1987; Altiner, 1999) and its repercussions on Central Europe (Grüntal \& Stromayer, 1992), as well as with the geological field measurements, (Fig. 2), (Prelogović et al., 1998).

The possibility to calculate the strain and stress orientation from doline distribution quantitatively confirms the strong rela-

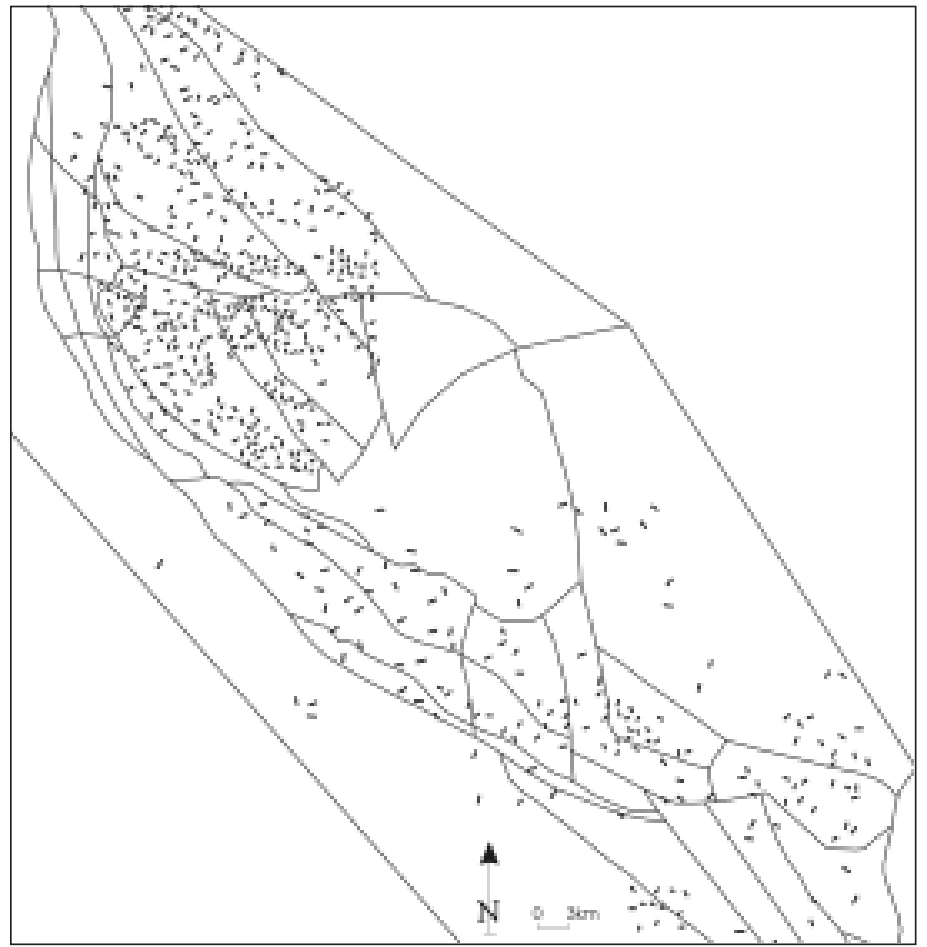

Fig. 1: Distribution of the 623 results from doline measurement on the Velebit mountain range. 


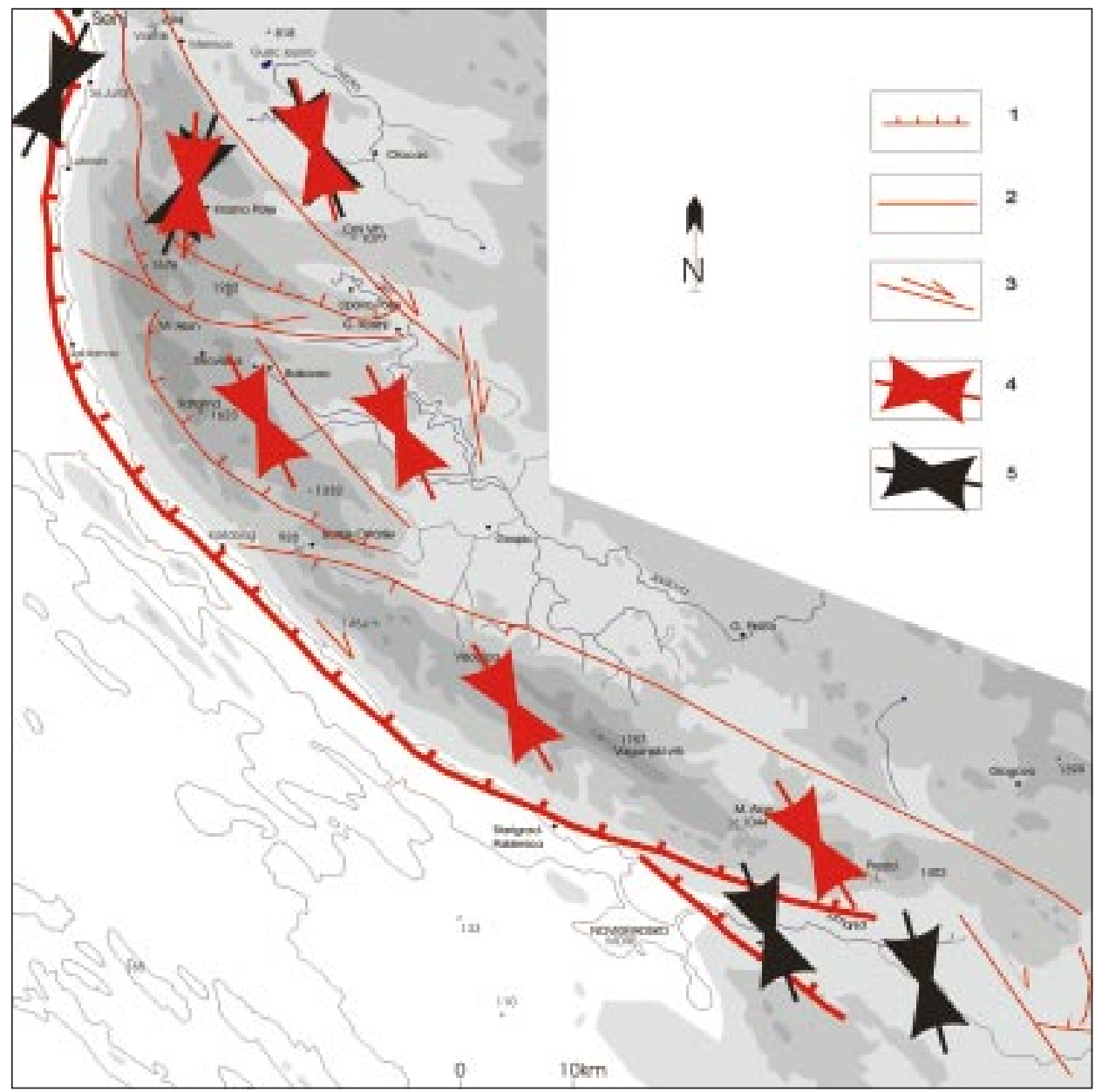

Fig. 2: Comparison between stress orientations results of the field measurements (Preologovic et al., 1998) and results obtained by doline measurements. 1-inverse faults; 2-normal faults; 3-strike-slip faults; 4-stress direction obtained from doline distribution, summarised using the Panozzo's method; 5-stress orientations obtained from field measurements (Prelogović et al., 1998).

tion between the geological structure and doline spatial distribution. Consequently, the observed deformations are the repercussion of tectonic displacements. Therefore, this study has a dual aim. First, to test the compatibility of the results obtained using the centre to centre method. If the results are mutually compatible, as they are supposed to be, they have to function as a unit. The second aim is to obtain the tectonic movements from the finite element model, which are directly connected to the doline distribution. Thus, the results of stress and strain measurements are injected into the finite element model. The data bases obtained from doline measurements are the only added parameter in different further analyses effectuated in the fault-block environment. 


\section{STUDY AREA}

The Velebit mountain range spreads over $2274 \mathrm{~km}^{2}$ with length of $145 \mathrm{~km}$ and with the highest point of $1757 \mathrm{~m}$ at Vaganski vrh. It is one of the biggest elevations in the Republic of Croatia and the longest mountain range of the Dinarides mountain system. It extends along the Adriatic coast in a NW-SE direction. The studied area consists of three main orographical units: north Velebit, central and south Velebit.

The distinct domination of carbonate rocks (limestones and lesser dolomites), specific climate properties, together with the tectonic states, play a major role in the morphogenesis of the karst relief. Its strongly fractured carbonate sediments provide a great predisposition for doline development. The great frequency of these forms allows us to undertake the proposed study. We find approximately 40000 dolines on the Velebit mountain range. The doline density is particularly high in the northern and central part where we find as many as 121 dolines per square kilometre.

\section{TECTONIC SETTING}

The structures of the Dinaric and Adriatic areas are characterized by inverse and thrust relations. They are the consequence of the gradual movements of the Adriatic microplate and the deformation of the Earth's crust in the narrow zone of the European plate. Major features can be coherently interpreted as consequences of a succession of shortening mechanisms and block readjustments, driven by convergence between Africa and Eurasia. It is known that the regional stress, approximately SW-NE in orientation, formed the structures of Velebit. The recent Quaternary period is characterized by reorganization of the structure of Velebit by refolding and new faulting with a stress approximately N-S (Prelogović, 1995). This change in the stress orientation is the result of the change in motion of the Adriatic plate from a NE to a NNW direction. The consequence is the accentuated compression or the rotation of structures that are unfavorably oriented to the new stress.

Anticline folding and high degree of fracturing characterize the Velebit mountain range. The faults represent a major characteristic of the structural unit. The most important one is the fault of Velebit (1 at Fig. 3). It is an overthrusted reverse fault with an overturn to the SW and S. The whole Velebit fault zone situated on the littoral side of the mountain is characterized by faults of the same type. Thrusting occurred on those shallow landward-dipping faults (Anderson \& Jackson, 1987). The inland faults are of relatively strong inclination with frequent variation. Recently the regional faults have been successively reactivated as right lateral strike-slip faults. The most important faults are those which determine the three major parts of the Velebit mountain range.

\section{FINITE ELEMENT METHOD}

The finite element method (FEM) has recently become one of the most popular and effective numerical procedures for boundary and eigenvalue problems. Its development has yielded a powerful tool for the analysis of structures in the rock because it makes possible an integrated analysis of composite structures (Goodman et al., 1968). The finite element method represents an impor- 


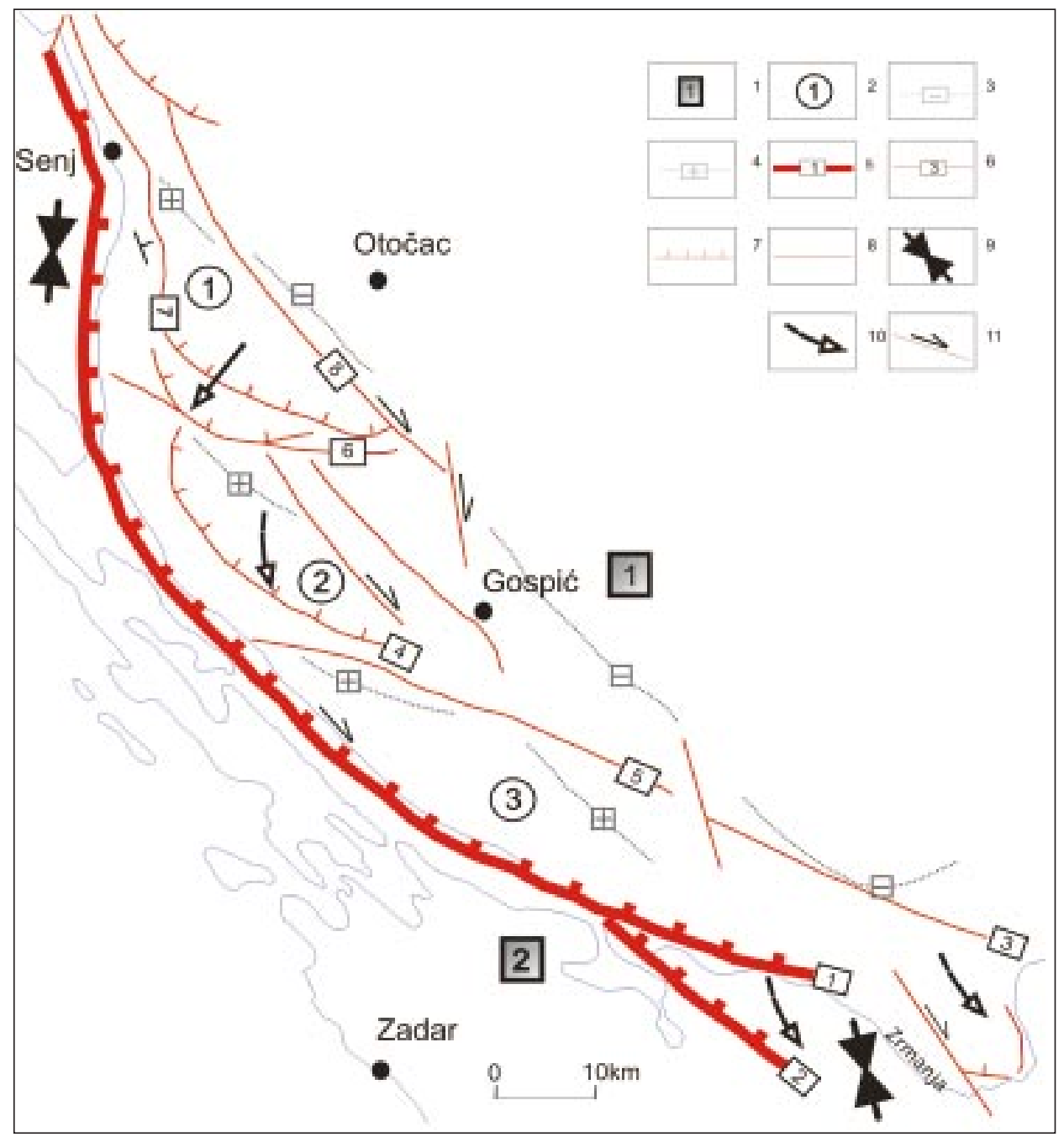

Fig. 3: Structural map of the studied area, (Prelogović, 1995).

Geological structures: 1. Regional structures of Dinarides: (1) Adriatic, (2) Dinaric; 2. Main parts of the structural unit of Velebit: (1) north, (2) central (3) south; 3. Axes of minimal gravimetrical anomalies (they represent a zone of the greatest subsidence of rock masses in depth; 4. Axes of maximal gravimetric anomalies (they represent the position of rock masses of great density near the surface;

Faults: 5. Regional faults: (1) fault of Velebit, (2) fault Obrovac-Drniš-Klis; 6. Faults which border main structural units of Velebit: (3) fault of Lika, (4) fault of Brušani, (5) fault of Oštarije, (6) Bakovac fault, (7) Senj fault and (8) Senjsko bilo fault; 7. Reverse faults; 8. Faults without defined character; 9. Regional stress; 10. Sense of movements of structures at the surface; 11. Faults with horizontal (slip) component of tectonic movement. 


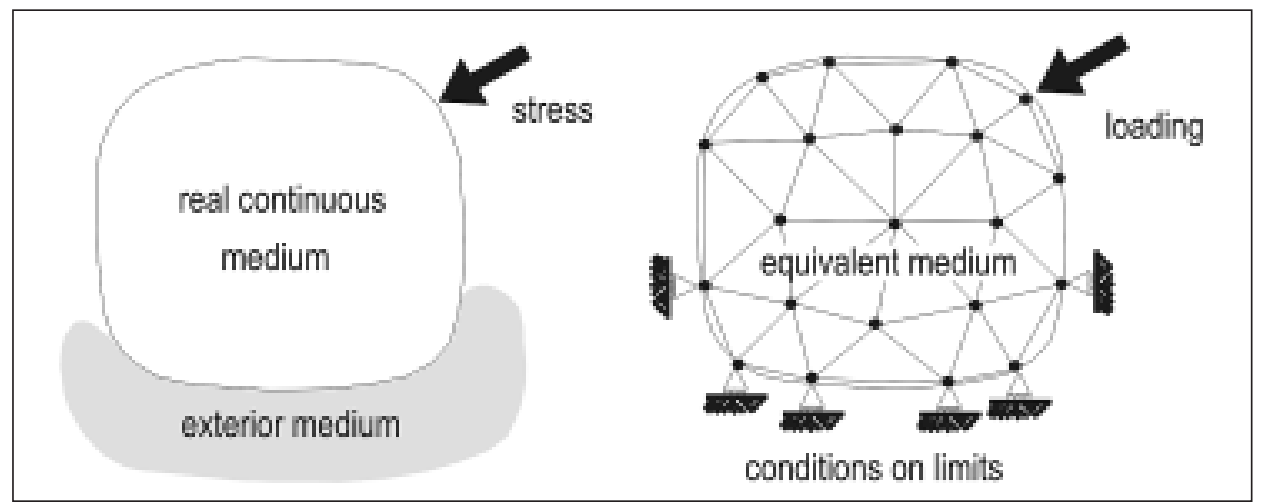

Fig. 4: Principle of the finite element method.

tant scientific tool and can be simply applied in tectonic geomorphology. It assumes knowledge of the basic laws of mechanical behaviour of considered rocks. The finite element method offers multiple possibilities in comparison with analytical models: it takes into account more realistic behaviour of the rocks (non-linearity, anisotropy, elastic-plasticity), the discontinuities of the structure (e.g. fractures), and variable loading. The basic idea consists of the definition of a certain finite number of simple geometrical elements (Fig. 4) mutually linked with a finite number of nodes (nodal point - corners of elements in the finite element grid, or mesh).

The calculation was done with the help of the program KINEMATICS written by Reiffsteck in the CASTEM 2000 (CEA 95). It is a code which allows treating of a great variety of mechanical problems. Since the program is object-oriented it allows the simple definition of geometry, the loading, and the definition of the boundary conditions of the studied zone.

\section{CONFIGURATION OF THE MODEL}

\section{Geometry and size}

The doline is a relief form, so the obtained ellipses may only reflect surface properties. Therefore, the two-dimensional numerical model has been adopted with the hypothesis of the plane strain. They are of course largely simplified in comparison with actual patterns, but can be used for the first-order approximation.

The model of the Velebit mountain range is much generalised. It is divided into 39 main blocks (Fig. 5). The principal faults have been chosen and also the ones which are needed to define the contours of the blocks. The structural map of Prelogović (1995) has been used as a base. The western side is delimited by the main Velebit fault below the sea and the eastern side greatly by the Gacko polje fault. Those blocks represent major structural units according to the tectonic setting which are considered homogeneous. The studied zone has been enlarged, particularly on the eastern side, due to the expected problems on the border zones of the model. We find this size sufficient to prevent edge effects from disturbing the stress field in the area of major interest. The Velebit fault-block geometry was created in the Arc/Info program (GIS). 
The choice of the grid type is another important factor that influences the degree of precision. The best homogeneity is aimed even if the form and the size of blocks are important. The triangular elements are used to create a mesh due to its simplicity and to the possibility of accommodation to complex forms (Mestat, 1993). 1085 nodes of the mesh are used at the beginning and the programme adds 1723 nodes to effectuate the entire calculation.

\section{Boundary conditions}

According to the background researches the boundary conditions are one of the most important factors (Fig. 5). If the studied area were considered as a continuous medium with a purely elastic rheology, the edge effects would represent a serious constraint in modelling. Therefore, the Velebit fault-block model is constructed as a discontinuous medium and is defined with elastic-plastic interfaces, so the edge effects have a minor influence. It is the internal kinematics that allows the absorption of deformation. In addition, the land boundaries have been modelled by the interfaces that allow the simulation of the infinite medium.

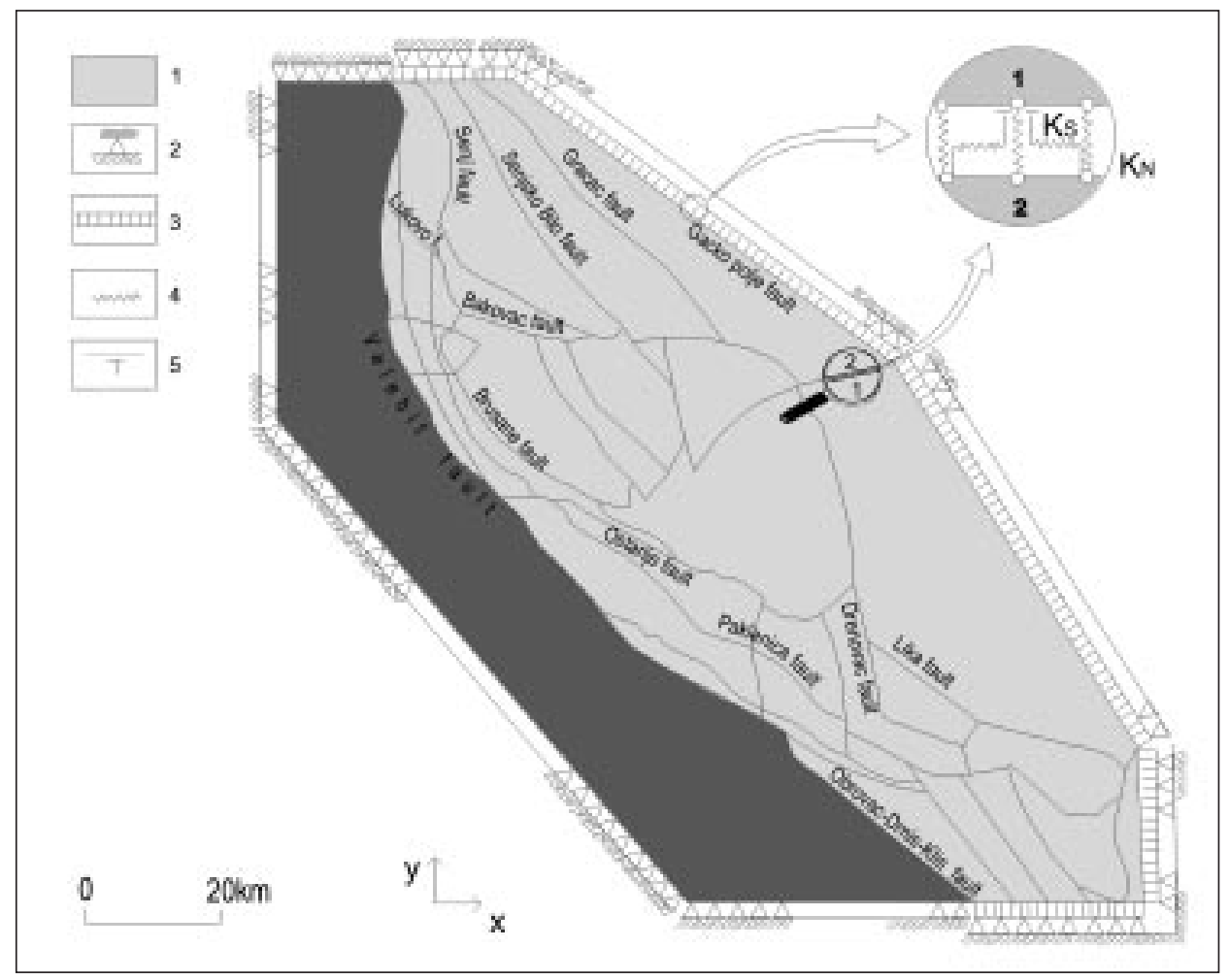

Fig. 5: Geometry with schematic boundary conditions of the studied area.

Boundary conditions: 1- elastic material-rock; 2-fixed points on $x$ and $y$; 3-interface elements (on the inland boundaries and faults);

Rheological model: 4-spring (Ks, KN); 5-plastic yield. 
The eastern and western external boundaries are blocked for the movements on the $\mathrm{x}$ - horizontal axis and on $y$ - vertical axis. This means that the position of the boundary points cannot be changed without a direct displacement applied on them. Between the boundary and the elastic material, the interface simulates the continuity of the medium using judicious elastic modulus in order to obtain the rigidity which corresponds to the one of the Dinarides. The links between different blocks constitute the internal boundaries. They are represented by the interface elements, which simulate the functioning of faults.

\section{Loading conditions}

There are several ways to apply load on a finite element model, either internally or externally. In our model we have applied internal loading conditions. The easiest way to apply internal loading is to give an initial stress on the springs whose behaviour defines the rheological model of the interface elements. The faults will slip, open or close till the resolution.

\section{Rheological models and properties of materials}

The use of simple rheological models is another major simplification. We use an elastic model for rocks and an elastic-plastic for faults with Mohr Coulomb criteria, appropriate for deformation within the brittle upper crust (Hu et al., 1996). The Mohr Coulomb criteria have been used to define plasticity.

\section{Rock behaviour model}

One of the simplest and perhaps most familiar stress-strain equations is the one for a linear elastic solid. Such a material deforms by an amount proportional to the applied stress. It means that the stress and strain have linear relationship. In the further models the elastic behaviour is proposed for the rock masses that is for blocks. It is characterised by Young's Modulus E, its Poisson's ratio $v$ and its density. Those models are chosen due to their capacity in the realistic representation of material behaviour and the possibility of simple determination of the entry parameters. It was also used by Grünthal \& Stromeyer (1992), Hu et al. (1996), Bada et al. (1998a) and Bada et al. (1998b) who assumed plates as elastics with non-uniform values of the Young's modulus and Poisson's ratio.

\section{Fault behaviour model}

Every fault is linked to the surrounding material by the interface elements. All points have a contact with the nearest point on the opposite side of the interface. The fault behaviour model is characterised by the elastic-plastic model with the Mohr Coulomb criteria and the law of separation that allows the interface to open. During all steps of calculation the increment of displacement is determined for all points. The increment vector of displacement on the point of contact is calculated in the normal and tangential direction. In this way the normal and tangential forces are determined.

Those interfaces are characterised by an angle of friction, the cohesion, the compression and the shear modulus. The criterion of plasticity for shear is the criteria of Mohr Coulomb. The corrected forces are then distributed on the adjacent nodes in the way to obtain the equilibrium of movements. They are added to other forces in every step of the calculation. 


\section{Parametric study}

The models are tested with a variety of values in order to explore the effects of changes in parameters and the sensitivity of results to various choices. That is, the mechanical properties like the Young's modulus attributed to different zones and the rheological model of interfaces used for the simulation of faults. The blocks will be always considered as elastics.

\section{Variation of the elastic modulus}

It is of course more realistic to use a different Young's modulus for every different kind of rock; however, it assumes their accurate knowledge. The values of modulus obtained from the previous finite element studies (Grünthal \& Stromeyer, 1992; Hu et al., 1996; Bada et al. 1998a; Bada et al. 1998b) have been used.

In order to investigate this question two models have been created: one with a single elastic modulus and the other one with different modulus defined according to the lithological maps. If the same elastic modulus is attributed to the whole studied zone, the difference between the minimal and maximal values of stress, strain and displacements is greater then in the case when it varies with the surface lithology. The latter allows the smoothing of values. It is the consequence of greater deformation of zones, which have lower values of the elasticity modulus when they are situated between two, confined more rigid zones.

Grünthal \& Stromeyer (1992), Angelier et al. (1994) and Hu et al. (1996) have concluded that tests of the Young's modulus $E$ variation, from 1 to $100 \mathrm{Gpa}$, do not cause substantial changes of the calculated maximal stress orientations. Angelier et al. (1994) found that the stress trajectories have very little sensitivity to the absolute values, and that they are moderately influenced by the ratio of these parameters. Therefore they are kept constant throughout the models. During the following study only two different values of the modulus will be used for all elastic zones. The western block simulating the Adriatic microplate is defined as stiffer than the continental zone. The properties used for the Adriatic plate are $\mathrm{E}=100 \mathrm{GPa}, \mathrm{v}=0.3$, and for the continental part, that is the Velebit mountain range $\mathrm{E}=70 \mathrm{GPa}, \mathrm{v}=0.3$ ( $\mathrm{E}=$ Young's modulus, $\mathrm{v}=$ Poisson's ratio).

\section{Rheological model of interfaces}

The choice of one model of behaviour for the interfaces, perfectly elastic or elastic perfectly plastic with the Mohr Coulomb criterion of failure has important consequences on the model. As a matter of fact, it is the passage from the continuous to the discontinuous medium, to a mountain range, which obeys to the mechanism of blocks. While in the continuous model one must operate with modulus (Grünthal \& Stromayer, 1992), or impose the concentration of stresses (Ronald et al. 1985), in the discontinuous massifs the apparent plasticity is obtained by the displacement between blocks. Moreover, it is not obvious that the previous ones are more representative of the physical phenomenon. The values used in the model are: $\mathrm{Ks}=11000 \mathrm{MPa}, \mathrm{K}_{\mathrm{N}}=25000 \mathrm{Mpa}$, $\mathrm{E}_{\mathrm{F}}=25000 \mathrm{MPa}, \mathrm{E}_{\mathrm{CN}}=0.1, v=0.3, \phi=25^{\circ}$ where $\mathrm{K}_{\mathrm{N}}$ and $\mathrm{Ks}$ are respectively the stiffness of normal direction (in compression and extension) and in the tangential direction. The threshold $E_{C N}$ of the normal deformation determines the passage from $K_{N}$ to $E_{F}$, the second normal stiffness. $\phi$ is the angle of friction at the interface, and $v$ the Poisson's ratio. 


\section{INJECTION OF MORPHOTECTONIC DATA IN THE FAULT-BLOCK MODEL}

We attempt to insert the results of the doline calculation into the finite element model. We have the orientation of 623 ellipsoids of recent deformation and their coefficient of ellipticity obtained from dolines. This model uses those results to calculate the stress and strain field on the nodes of the grid that was created in the model. The interpolation was done for every block separately. Then different blocks are assembled. Thus the basic strain field has been obtained from the analysis of doline distribution. Eight blocks do not contain any information. They are, of course, the blocks that were added east and west from the studied zone to avoid edge effects over the studied area. The program proceeds toward the resolution till the convergence of data, that is, until the necessary deformations are obtained which equilibrate the inserted values. It must be reminded that the boundaries are fixed and no displacements added, because the aim of this model is to test and obtain pure results from doline measurements.

\section{RESULTS}

The obtained values on every node of the grid were used for the further analysis. First, the principal stress axes were calculated, which simple interpretation is rather difficult. The most striking fact is the increasing of compression along the coast. This absolutely coincides with the surface dilatation map (Fig. 6) obtained from the GPS measurement (Cigrovski-Detelić, 1998; Altiner, 1999) where the area of strongest compression borders the Velebit mountain range.

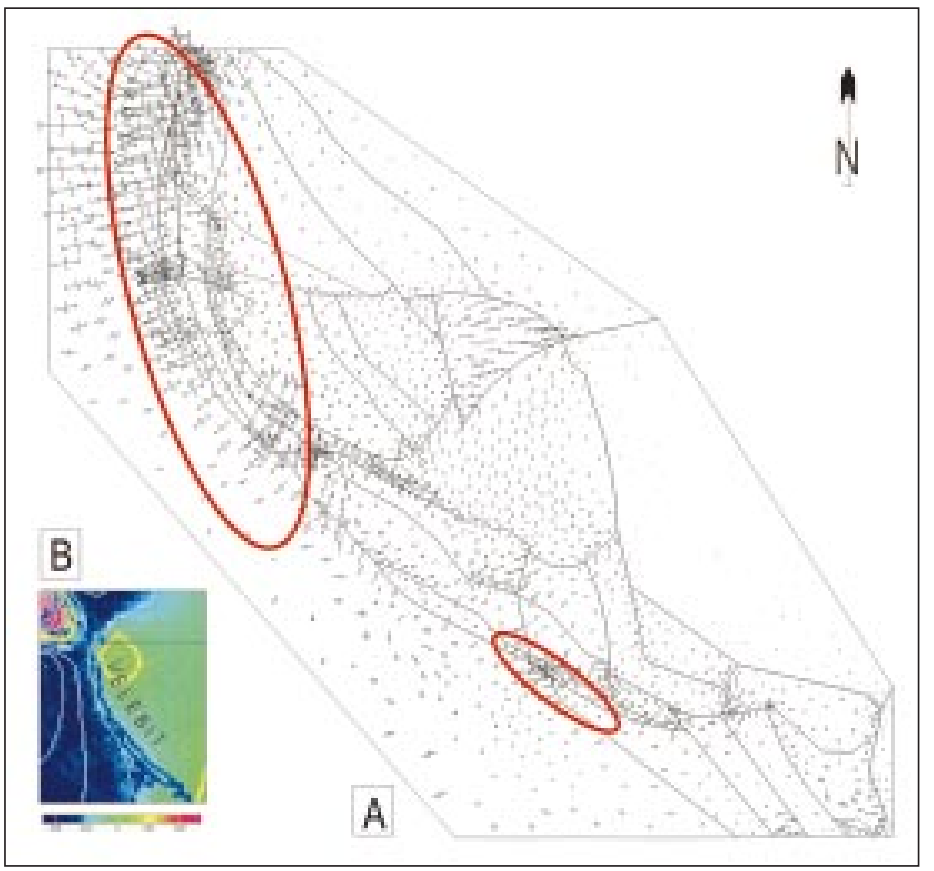

Fig. 6: A- Distribution of stress orientations obtained from the finite element model. B-Section of the surface dilatation map (after Cigrovski-Detelić, 1998 and Altiner, 1999). The area with the positive sign of dilatation characterises the zone of extension (red colour) while the negative sign indicates the narrowing of the area that is the compression (blue colour). 


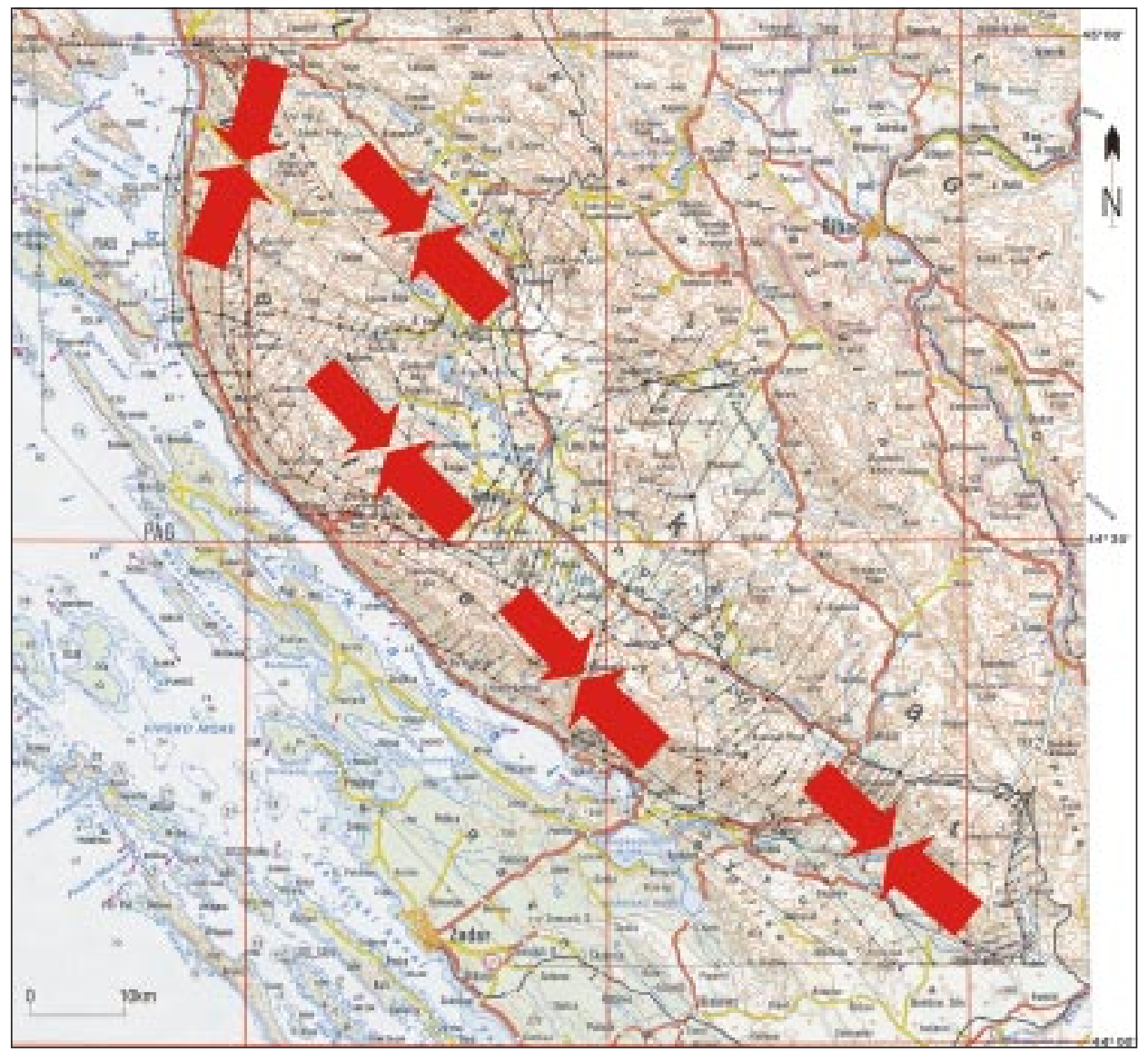

Fig. 7: Strain trajectories with maximal stress orientations indicated with arrows.

Then the strain orientations were obtained. To facilitate the interpretation of the strain distribution through the studied area an integration from one point to another was necessary. Therefore, the strain trajectories were traced over the studied zone. As it can be seen on the Fig. 7 they are generally oriented towards the NE-SW with the exception of the western part of the north Velebit where the strain trajectories are oriented NW-SE. Consequently, the general maximal stress orientation is NW-SE, and for the western part of the north Velebit NE-SW. The results are much smoothed and are relatively close to those obtained by Panozzo's method as well as to those obtained from the geological field measurement (Fig. 2) (Prelogović et al., 1998). The trajectories sometimes intersect because it is an assembly of separately studied blocks. Trajectories depart from the nodes of the mesh. Their length depend on the strength of the «a» (the longest ellipse axis) and on the calculation time the particles need to cross the studied area.

The relative movements of structures, that is the resistance of the rock masses to the movements of the Adriatic microplate were also expressed using the trajectory method. In the north 


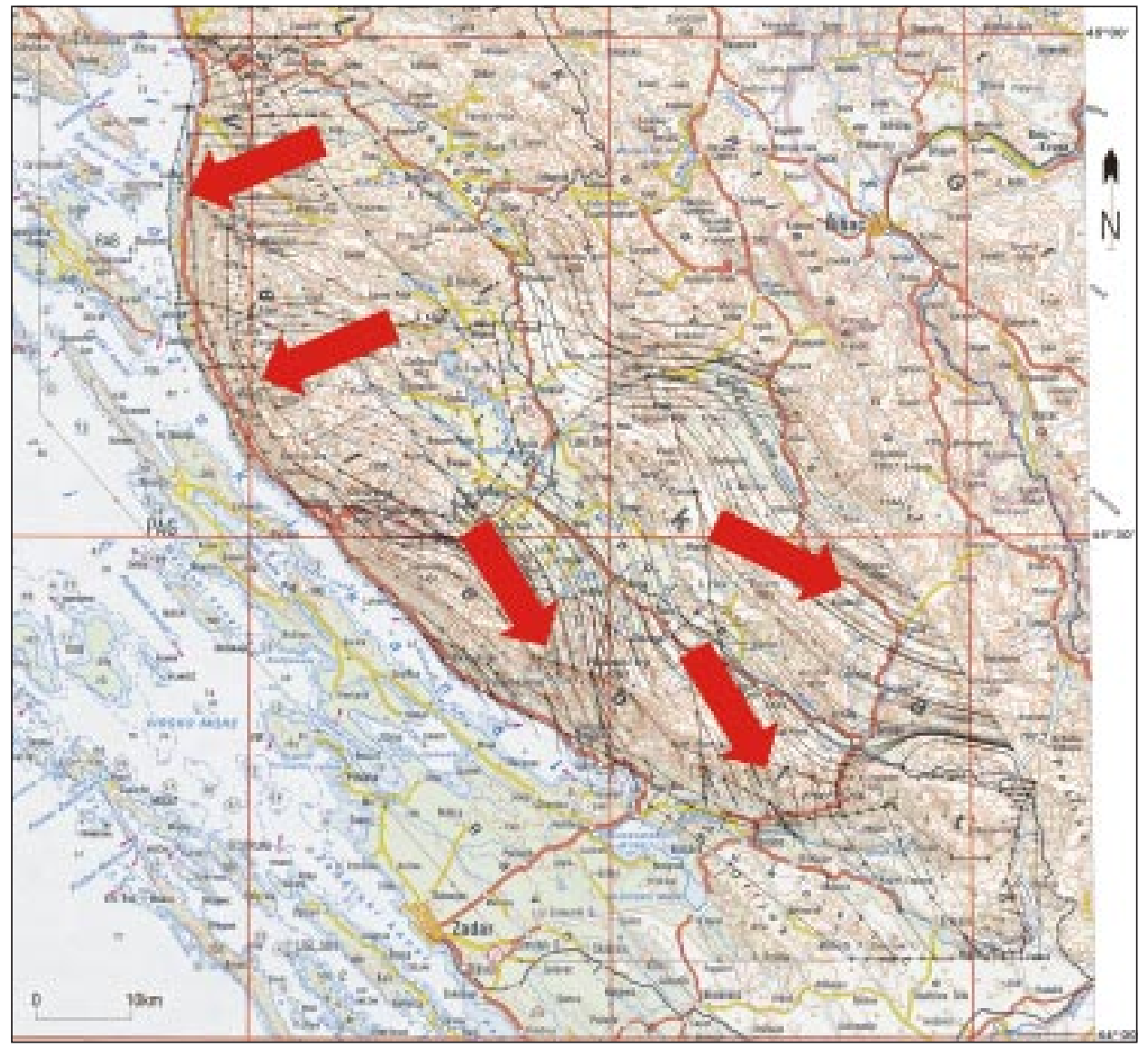

Fig. 8: Trajectories of relative displacement.

and central Velebit the relative movements occurred more toward W and SW, while in the southern Velebit toward SE (Fig. 8). They generally correspond to the facts shown in the Fig. 3. (Prelogović, 1995).

The program also allows us to calculate the spatial variation of the shear stress over the studied area Fig. 9. The blue and red colour emphasise the areas of increased shear, but of the opposite direction. The strike slip motion along the main Velebit fault (in blue colour) is particularly well marked.

On the inland faults the shear can also be seen. The Senj fault is distinguished in the north Velebit. The Brušane, Karlobag and Oštarije faults can be distinguished in the central and south Velebit as well as the area near Starigrad Paklenica. This map also coincidences with the movements find on the structural map (Fig. 3) as well as with the movements of the Adriatic microplate Fig. 10. 

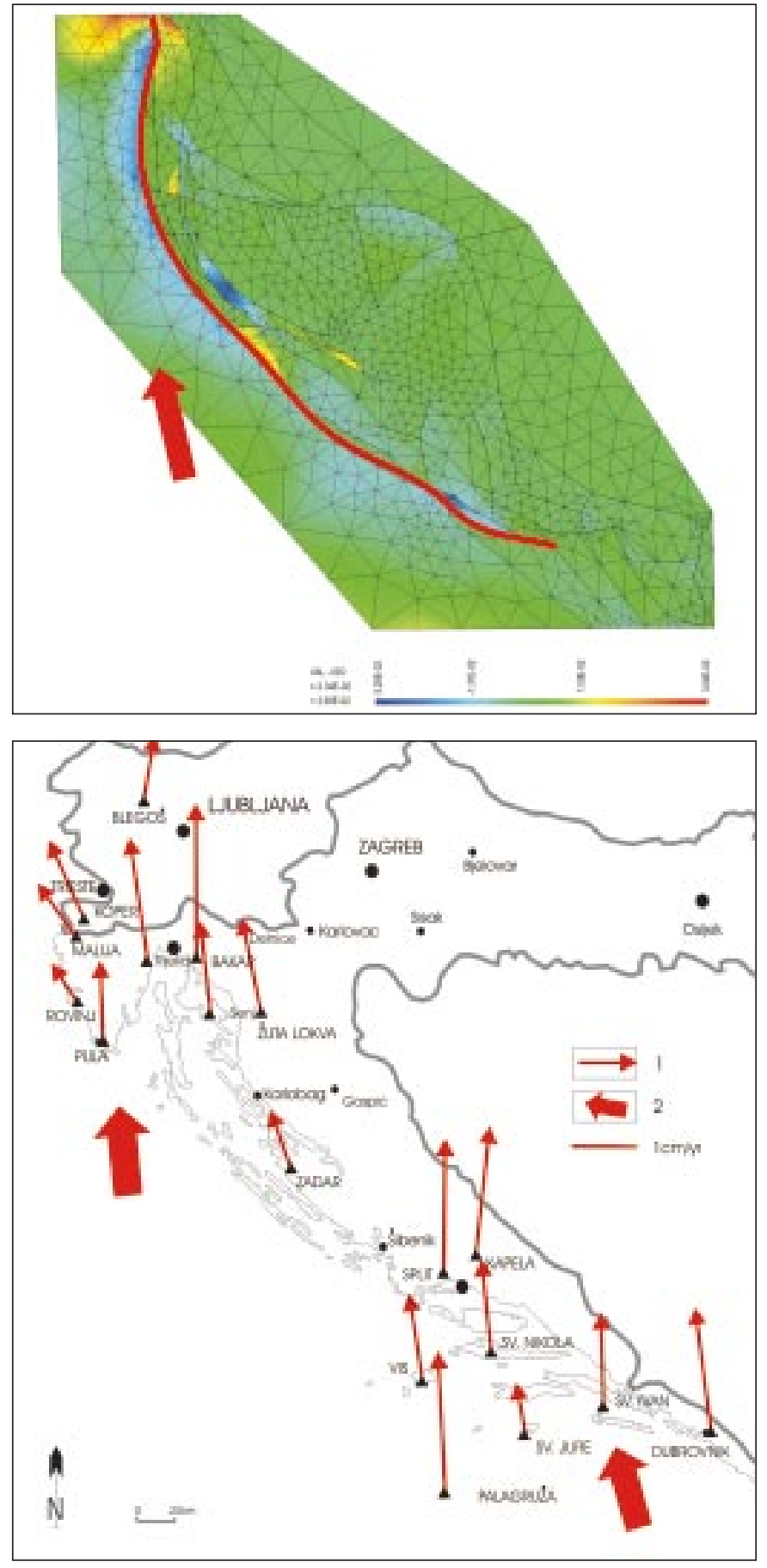

Fig. 9: Distribution of shear stress on the Velebit mountain range. Maximal stress values in blue and red colour, indicating different movement directions.

\section{CONCLUSION}

The simplified 2-D finite element models are quite useful in recognizing and interpreting the strain-stress relationships in the Velebit mountain range and surrounding area. The use of the trajectory method is particularly helpful because it allows the geometrical synthesis of a large number of local results in a rigorous geometrical way, as well as the possibility of easy interpretation and comparison between differently obtained results.

Fig. 10: Results of the GPS measurements (after Cigrovski-Detelić, 1998 and Altiner, 1999). 1-horizontal component of the movement velocity vector; 2-movement of the Adriatic microplate. 
Our modelling results show that the numerous results obtained from doline distribution is mutually compatible and can function as a unit.

The models made on dolines allow us to conclude on a few points: the increasing compression near the coast, the shear stress along the Velebit fault, the difference in relative displacements between the north and central Velebit, where movements occurred toward W and SW and the south Velebit where they occurred toward the SE, and on general strain and stress orientations which are in accordance with the motion direction of the Adriatic microplate.

These results show a general coincidence between the calculated stress pattern and the in situ measurements (Prelogović and Buljan, 1998).

They also demonstrate that the relief forms show the close relation with the general properties of the present-day stress field in the Velebit mountain range, that is the close connection of doline distribution with recent deformations of the area.

\section{ACKNOWLEDGEMENTS}

Grateful acknowledgements to Eduard Prelogović, Professor at the Zagreb University, for helpful suggestions and discussions.

\section{REFERENCES}

Angelier, J., Lee, J.-C. \& Hu J.-C. 1994: Construction of Trajectory Maps Based on Local Paleostress Determinations and Their Interpretations: Some New Insights, In: Roure, F. (Ed): Peri-Tethyan Platforms.- Technip, p. 129-143, Paris.

Anderson H. \& Jackson J. 1987: Active tectonics of the Adriatic region.- Geophys. J. R. astr. Soc. 91, p. 937-983.

Altiner, Y., 1999: Analytical surface deformation theory for detection of the Earth's crust movements.- Springer Verlag, p. 100, Berlin, Heidelberg, New York.

Bada, G. \& Horvath F., 1998a: Present-day geodynamics of the Pannonian basin and its surroundings: a review.- Reports on geodesy, No.5 (35), p. 51-75, Warsaw.

Bada, G., Cloethingh, S., Gerner, P. \& Horvath, F. 1998b: Sources of recent tectonic stress in the Pannonian region: inferences from finite element modelling.- Geophys. J. Int. 134, p. 87-101.

Cigrovski-Detelić B. 1988: The use of GPS measurements and geotectonic information in the analysis of the CRODYN geodynamic network.- Unpublished Ph.D. Thesis, University of Zagreb (in Croatian), p.145.

Faivre, S., Reiffsteck, Ph. 1999a: Spatial distribution of dolines as an indicator of recent deformations on the Velebit mountain range.- Géomorphologie: Relief, Processus, Environnement, 129-142. Paris.

Faivre, S., Reiffsteck, Ph. 1999b: Measuring strain and stress from sinkhole distribution, Example of the Velebit mountain range, Dinarides, Croatia.- Proceedings of the Seventh Multidisciplinary Conference on sinkholes and the engineering and environmental impacts on karst. Eds: B. F. Beck, A. J. Pettit \& J. G. Herring, p. 25-30. A. A. Balkema, Rotterdam, Brookfield. 
Faivre, S., Bocquet, J-F. 1999: Variation spatiale des contraintes tectoniques calculées a partir des dolines; Montagne de Velebit, Croatie.- Etudes de géographie physique. Travaux 1999Supplément $n^{\circ}$ XXVIII CAGEP, Université de Provence, p.83-88.

Fry, N. 1979: Random point distributions and strain measurement in rocks.- Tectonophysics, 60, p. $89-105$.

Goodman, R.E., Taylor, R.L. \& Brekke, T.L. 1968: A model for the mechanics of jointed rock. Journal of the soil mechanics and foundations division.- Proceedings of the American Society of Civil Engineers, May 1968, SM3, p. 637-659.

Grüntal, G., Stromeyer, D. 1992: The recent crustal stress field in central Europe : trajectories and finite element modelling.- J. Geophys. Research, Vol. 97. No. B8, p.11805-11820.

Mestat, Ph. 1993: Lois de comportement des géomatériaux et modélisation par la méthode des éléments finis.- Rapport de recherche LPC - GT52, p.193.

Hu, J-C, Angelier, J., Lee, J-C., Chu, H-T., Byrne, D. 1996: Kinematics of convergence, deformation and stress distribution in the Taiwan collision: 2-D finite-element numerical modelling.- Tectonophysics, 255, p. 243-268.

Panozzo, R. 1984: Two-dimensional strain from the orientation of lines in plane.- Journal of Structural Geology, Vol.6, No.1/2, p. 215-221.

Prelogović, E, 1995: Geological structure of Velebit mountain range.- Paklenički zbornik Vol.1, Simpozij povodom 45. Godišnjice NP «Paklenica », Starigrad-Paklenica, p. 49-54. (in Croatian).

Prelogović, E., Kuk, V., Buljan, R. 1998: The structural fabric and seismotectonic activity of northern Velebit: some new observations.- Zbornik RGN fakulteta, Vol.10., Zagreb.

Ramsay, J.G. 1967: Folding and fracturing of rocks.- Mc Graw Hill, New York, p.568.

Ronald, E., Wilcox, T., Harding, P. \& Seely, D.R. 1985: Basic Wrench Tectonics.- In: Sylvester, A.G. (Ed): Wrench Fault Tectonics.- The AAPG, Tulsa, Oklahoma U.S.A., p.290-313.

\section{POVEZAVA MED RAZPOREDITVIJO VRTAČ IN TEKTONIKO: PRIMER GORSKE VERIGE VELEBIT NA HRVAŠKEM}

\section{Povzetek}

Članek obravnava povezavo med tektonskimi silami in kraškimi površinskimi oblikami. Smer deformacij in napetosti v Velebitskem masivu smo izračunali na osnovi razporeditve vrtač z uporabo metode "center-center" (Ramsay, 1967; Fry 1979).

$\mathrm{V}$ ta namen smo izdelali bločni model Velebitskega masiva v katerem posamezne bloke ločijo prelomi. Nekaj blokov na vzhodu in zahodu je dodanih brez predhodnih podatkov zaradi numerične stabilnosti modela. Da bi v modelu upoštevali zgolj meritve vrtač, smo kot robni pogoj predpostavili ničelno deformacijo na zunanjih mejah.

623 rezultatov lokalnih meritev smo interpolirali na 1085 vozlišč mreže modela končnih elementov, ki na osnovi tega izračuna razporeditev deformacij in napetosti v celem območju. Rezultat modela je razporeditev napetosti in deformacij, ki ustrezajo tektonskim razmeram v masivu. Dobljene rezultate smo primerjali z GPS meritvami in rezultati geološkega kartiranja in ugotovili veliko stopnjo ujemanja. 